University of Warwick institutional repository: http://go.warwick.ac.uk/wrap This paper is made available online in accordance with publisher policies. Please scroll down to view the document itself. Please refer to the repository record for this item and our policy information available from the repository home page for further information.

To see the final version of this paper please visit the publisher's website. Access to the published version may require a subscription.

Author(s): Shaun Breslin

Article Title: The politics of Chinese trade and the Asian financial crises: questioning the wisdom of export-led growth Year of publication: 1999

Link to published version: http://dx.doi.org/ 10.1080/01436599913352

Publisher statement: None 


\section{The Politics of Chinese Trade and the Asian Financial Crises: Questioning the Wisdom of Export-Led Growth}

Shaun Breslin, Centre for the Study of Globalisation and Regionalisation, University of Warwick

NB Tables are not available in this document - please refer to the published version in The Third World Quarterly for tabular statistics.

\section{ABSTRACT}

Between 1987 and 1996 Chinese exports increased by an average of 14\% each year. During this decade, export growth became a crucial determinant of overall economic growth. However, as a consequence of the East Asian financial crises, Chinese export growth slowed, threatening the successful implementation of plans to restructure the domestic Chinese economy. This paper traces the reasons for the rapid growth and subsequent slowing of Chinese exports, and asks whether the strategy provides a solid basis for the long term development of the Chinese economy. In particular, the paper focuses on the role and significance of the processing trade in boosting Chinese exports. The high proportion of imported components in processed exports questions whether China is really benefiting as much from export growth as aggregate trade figures seem to suggest.

When China embarked on a process of economic reform in 1978, it was rare to find Chinese-made goods on sale in the West. China was not a major trading nation, and what it did trade was overwhelmingly in primary produce with other developing nations. Twenty years later Chinese trade had increased by almost 500\%, the developed world now predominated in Chinese trade, and manufactured goods accounted for almost $90 \%$ of China's exports to OECD countries-the 'Made in China' stamp is now common throughout the world.

While not denying that export growth has clearly contributed to the growth of the Chinese economy as a whole, this paper offers a critical examination of the benefits of pursuing an export-led growth strategy. This investigation is divided into two main levels of analysis. First, rather than taking a national approach and asking if and how China has benefited from a growth in trade, the paper disaggregates Chinese export figures and asks who is benefiting most from the growth of Chinese trade? On one level, we see strong regional disparities in export performance. On another, we need to question whether exports from China can be meaningfully described as being 'Chinese'. The large growth in Chinese trade is in no small part a result of the relationship between foreign direct investment (FDI) and trade, 
and China's position in an international chain of production. Indeed, we should question whether nationally based trade statistics reveal very much about the dynamics of international trade and the `nationality' of trade.

Second, the Chinese experience illuminates how a dependence on export-led growth can create asymmetrical dependence on external economic actors. This issue becomes particularly pertinent when domestic growth is slow - as was the case in China in 1989, and again after 1997. An analysis of China's export performance in the 1990s shows both how China at least contributed to the economic difficulties of other export-orientated states in East Asia, and also how the financial crises place question marks over the long-term wisdom of China's own export growth strategy.

\section{Tracing the growth in Chinese exports}

There is a tendency to describe China in the Maoist period as a ‘closed economy'. This popular perception rather exaggerates the level of isolation, and is primarily a product of equating the capitalist world with the international economy. As Zhang has demonstrated, while China did look to self-reliance where possible in economic development, foreign trade also played a role "as a balancing sector of the Chinese economy'. ${ }^{1}$ Nevertheless, despite the fact that trade increased after 1949, it is fair to say that China was not a significant player in the global economy during the Maoist era. After China's break from the Soviet Union and the gradual and moderate programme of re-engagement with the West in the 1970s, trade did increase, but trade volumes remained relatively low. Total Chinese trade was a meagre US $\$ 4.8$ billion in 1971 , and even after an almost five-fold expansion in trade, still only totalled $\$ 20.6$ billion in $1978 .^{2}$

But 1978 marked a watershed in Chinese economic policy. The initial moderate reforms initiated in 1978 gave only a strictly limited role for international economic interaction, and China's re-integration into the global economy was initially a slow and gradual affair. While rather modest compared with later changes, the adoption of a more open policy towards the global economy in 1978 marked a fundamental ideological shift that was a prerequisite for all that was to follow. Even remembering that Chinese trade has grown from a very low starting point, the growth in Chinese trade since 1978 has been spectacular. As the Director General of the World Trade Organization (WTO), Renato Ruggiero, put it in a speech at Beijing University in April 1997:

There is a simple reality which lies at the heart of our 
current negotiations and the real challenges of adjustment we all face: the reality that China is already a leading power in an ever more interdependent global economy. This reality is emphasised by the sheer force of China's rise in the world. During the last decade, output has been expanding by an average of 10 per cent a year, while merchandising export volume has been growing even faster, at about 15 per cent. In two decades the value of China's merchandise exports has expanded more than twenty-fold. ${ }^{3}$

\section{Methodological and statistical problems}

Before providing more details of this expansion in exports, it is important to provide a caveat on the problems of calculating Chinese trade, and its importance for overall economic growth. There are two main areas of dispute here. First, there is the question of the size of the Chinese economy. Chinese figures from the State Statistical Bureau used in all official Chinese reports calculated Chinese GDP in 1997 as RMB 7.48 trillion, which roughly equates to US\$900 billion. However, Purchasing Power Parity (PPP) calculations produce a much higher figure. For example, the CIA World Factbook calculates Chinese GDP in 1997 at \$4.25 trillion.4 Thus, China’s trade-to-GDP ratio for 1997 is $36 \%$ or less than $10 \%$ depending on which figures you use. The true size of the Chinese economy lies somewhere between Chinese and PPP calculations, but we can suggest with some confidence that trade is a less important element of the Chinese economy than initial figures seem to suggest.

Second, there is the question of calculating Chinese trade statistics. The trade data used in this paper primarily originate from the PRC General Administration of Customs. If anything, these figures understate the growth of exports (and therefore total trade and China's trade surplus) because of the difference between Chinese and Western methods of calculating exports. For example, according to US official estimates, the US-China trade imbalance in 1998 was around \$57 billion, while Chinese official data showed an imbalance of 'only’ \$21 billion.5

Part of the problem results from the fact that China calculates the value of exports as they leave China's shores (FOB calculations), while the USA and most other states calculate the value of those goods as they arrive in their country (FAB calculations). 6 However, a further and greater complication arises from the question of how to calculate bilateral trade that passes through a third place - most obviously Hong Kong. For example, China calculates that $60 \%$ of exports to the USA pass through a third place 
en route- primarily Hong Kong.7 According to Chinese statistics, on average, once the good leaves China, there is an extra $40.7 \%$ value-added in the third place, and in the case of toys and textiles, the subsequent value added even exceeds 100\%. As US statistics count exports through Hong Kong as Chinese exports, the Chinese argument is that this misses the huge value added that occurs once the goods leave China.

Feng and Liu have recalculated Sino-American trade taking into account the difference between FOB and FAB prices, re-exports through Hong Kong, and smuggling. ${ }^{8}$ They conclude that the Sino-US trade imbalance in 1998 was around \$35 billion-almost (but not quite) half-way between the Chinese and American figures. These discrepancies are not just a matter of statistical interest. As Chinese exports have boomed, so trade friction has increased between China and the USA in particular, and the West in general. And the size and importance (or otherwise) of China's trade surplus with the West varies depending on which figures you use. Thus, the Chinese authorities are accused by the West of deliberately deflating the importance of Chinese trade, while the Chinese accuse the West of unfairly exaggerating the significance of Chinese exports. Or as the then Minister of Foreign Economics and Trade, Li Lanqing, put it when Western governments questioned Chinese trade figures in 1992, "We are of the view that these trade imbalances [are] caused mainly by unreasonable methods of keeping international trade statistics."9

\section{Statistical survey}

Table 1 shows the growth in Chinese trade from the start of the reform period until 1996. Although Chinese figures deflate the value of exports, using a common set of statistics means that the growth figures may be more reliable than raw trade statistics. As these trade statistics are denominated in US dollars, the figures have been adjusted to common 1996 US dollars.

While long-term growth rates are clearly significant in themselves, the increase in Chinese exports between 1993 and 1995 warrants particular attention here. Exports increased by $60 \%$ in two years (53\% in real terms), and doubled between 1993 and 1997.10 In the process, a $\$ 12.2$ billion trade deficit in 1993 was transformed into a $\$ 5.4$ billion surplus the following year, rising to $\$ 40.3$ billion in 1997 . Considering the deflationary impact of Chinese export statistics, the increase in exports and the transition from trade deficit to surplus may be even more dramatic than these figures suggest. 
There are two main explanations for these changes. The first is the massive influx of FDI into China in 1993, an issue we will return to below. Second, and more important, was the 'restructuring' of China’s foreign exchange rate system in 1994. The Chinese currency, the Renminbi (RMB) Yuan, is not fully convertible on international markets, and exchange rates remain under central government management and control. However, in the early 1990s a market rate of sorts appeared as the government relaxed regulations on currency exchanges. To facilitate increased international economic contacts, a number of 'swap shops' were established, ${ }^{11}$ where individuals could 'swap' the Yuan for foreign currency. ${ }^{12}$ Although the official exchange rate at the time was RMB5.7 to the dollar, the swap shop rate was influenced by supply and demand, and was closer to RMB9 to the dollar.

Faced with this disparity, and a record trade deficit in 1993, the government 'unified' the two rates in 1994. This essentially entailed moving to the swap shop rate, with the new exchange rate of RMB8.7 to the dollar apparently representing a $50 \%$ devaluation. In reality, most companies did not obtain all of their foreign currency at the managed exchange rate, and were already using the market rate for a proportion of their foreign exchange dealings. As such, the headline 50\% devaluation was probably nearer $20-30 \%$ for most exporters. Nevertheless, this move increased the relative competitiveness of Chinese export - notably relative to the cost of exports from other states in Southeast Asia following export lead growth strategies.

\section{Competitive export led growth and the Asian financial crises}

China's own strategy was in part inspired by the success of export-led strategies elsewhere in Asia in spurring economic growth. But while difficult to quantify, China's decision to pursue a similar strategy helped to undermine the effectiveness of the strategy in other states. Indeed, the financial crises in Southeast Asia in some respects represented belated and drastic currency realignments in response to China's 1994 devaluation.

This is not to say that trade relationships in Asia represent a zero-sum game. However, it is the case that, when China re-entered the global economy, it began to compete with other export-orientated states for foreign investment, and competed with these states for access to the key lucrative markets of the USA, Japan and the EU. Table 2 shows the growth in trade with China's major partners from the start of the reform process in 1978 to 1996, while Table 3 shows the changing distribution of trade with those partners over the same period.

The directions of trade statistics are somewhat skewed by the special role of Hong Kong in Chinese trade. Before the start of the reform 
process in 1978, Hong Kong provided China's main link with the global economy, acting as a transit point for exports and imports with the capitalist world. Despite growing bilateral economic relations with other countries, China's special relationship with Hong Kong has remained intact, with trade between China and Hong Kong now the world's third biggest bilateral trade relationship (behind US-Canadian and US-Japanese trade).$^{13}$ Indeed, the percentage of Chinese exports to Hong Kong which are subsequently re-exported to other destinations increased from around $30 \%$ in 1979 to over $85 \%$ in $1994 .{ }^{14}$

If we factor in exports to Hong Kong that are re-exported to a third country, then the importance of the USA and Japan in particular as markets for Chinese exports increases. As Table 4 shows, with the addition of the EU, these three major markets take around twothirds of all Chinese exports. The Japanese and US markets were also the primary destination for exports of finished goods from other export-orientated states in Asia. And as Table 5 shows, there appears to be a correlation between the rise of exports from China to the USA and Japan, and a decline in exports from Asian crisis states to the same markets.

These figures, produced by the Japan External Trade Organisation, question how much room is there in the 'market place' for so many countries searching for the same FDI to produce the same goods for export to the same markets. The potential problem for late developing states emphasising low costs as a means of attracting investment to spur export-led growth is that an even later developer with even lower costs might erode their comparative advantage.

\section{Chinese export growth - who benefits?}

On the face of it, then, if the Chinese experience questions the wisdom of export-led growth, it is other export-orientated states that have been faced with problems rather than China itself. However, if we go beyond a simple analysis of trade figures, and ask who benefits from China's export growth, we identify a number of important political economy issues. In essence, we need to move away from a statist approach - asking if China has benefited towards a disaggregated approach asking who has benefited from the growth in Chinese trade?

\section{Uneven development}

First, we have to recognise that uneven development has been a key characteristic of the Chinese reform process. As Table 6 shows, Chinese 
export industries are concentrated in nine coastal provinces with Guangdong Province providing some $41 \%$ of all exports. Indeed, Shenzhen Special Economic Zone (SEZ) alone accounts for around $14 \%$ of all Chinese exports. ${ }^{15}$

Table 6 also includes information on the provincial distribution of FDI. The distribution for 1997 is in some ways unrepresentative of FDI flows since the start of the reform process. Guangdong's share of FDI in 1997 is low by historical comparison. In aggregate terms, Guangdong has attracted around $40 \%$ of all FDI into China since 1978. However, while Guangdong's share has fallen, the distribution has been within the coastal region, rather than from coast to interior.

FDI figures are provided here because of the crucial role that foreign investment has played in the growth of Chinese exports. Indeed, to understand the politics of export growth, it is essential to distinguish between 'domestic' Chinese exports, and foreign-funded Chinese exports.

\section{'Domestic' Chinese exports and protectionism}

Chinese state actors at both national and local levels have taken a proactive role in promoting export industries. In addition to the competitive currency devaluation of 1994 noted above, national and local authorities have introduced a number of measures to support exporters, particularly in the state-owned sector. For example, they have eased access to investment capital by providing loans through the creation of specialist banks, and provided a number of tax exemptions and other incentives for exporters.

Furthermore, US trade officials claim that the lack of full price reform in China also acts as a hidden state subsidy for those Chinese producers in the state sector, and even private enterprises that retain close and warm links with the state administration. ${ }^{16}$ The price of land, labour and key industrial inputs such as energy and steel are not solely or in some cases primarily set by market forces. While market forces are an increasingly important force in the Chinese economy, the state retains the authority to set prices and allocate resources of key productive forces. As these state-set prices are much lower than the prevailing market price, the retention of state control entails a hidden subsidy to favoured producers.

This state support for exporters is accompanied by significant protection for domestic producers from the impact of participating in the 
global economy. Access to the Chinese market remains restricted. China operates a system of mandatory import plans, and restricts licenses for imports of key commodities. The biggest restrictions here are on iron and steel, textile yarns and machinery - the critical sectors where inefficient domestic producers in the state sector are most vulnerable to international competition, and the sectors where exports from the state sector are strongest.

Chinese import tariffs remain among the highest in the world. Average tariff rates have been falling in response to international pressure. From a high point of $43 \%$ in 1992, they have been progressively lowered to around $17 \%$, with a promise for further reductions to follow. However, foreign exporters argue that the real tariff rate is nearer $40 \%$, as value added tax is always added to imports, while domestic producers are typically granted exemptions by local authorities.

Those foreign companies that try and gain access to the Chinese market by locating their operations in China also face discrimination, and find themselves subject to different charges and rules of the game than domestic producers in the same sector. For example, while Chinese producers, particularly in the state sector, will benefit from cheaper state set prices for key inputs, foreign companies usually have to pay the higher market rate for the same commodities. Chinese enterprises are also supported through massive subsidies, which often take the form of 'loans' from government or the banking system that will never be repaid. For example, the World Bank calculates that such non-performing loans account for $20 \%$ of the assets of Chinese banks, 17 and the Chinese State Statistical Bureau announced that unpaid loans to various levels of government accounted for $10 \%$ of Chinese GNP in 1995.18 Furthermore, incomplete currency convertibility restricts access to foreign currency to either the chosen few, or those operating within the designated production zones; it also means that converting and repatriating profits is difficult if not impossible.

Finally, there are two other issues that have brought international criticism of China's trade regime. The first is the wide-scale infringement of intellectual and property rights in China, where the production of counterfeit and fake products is commonplace. The second is the lack of transparency in China's policy-making process. The state news agency, Xinhua, has an official monopoly in the dissemination of economic information, and ensures that this information serves the interests of the Chinese state, rather than the interests of the international community. 
The international community has attempted to pressure China to liberalise its trade regime in a number of ways. The EU, for example, has refused to classify China as a ‘Market Economy’. As a result, the EU estimates the fair price for Chinese exports by comparing them with the price of goods from the most comparable market economy, in this case India. If the cost of Chinese goods is found to be unfairly low, then the exports are subject to the imposition of extra import duties to protect European producers under EU antidumping legislation. ${ }^{19}$ While the strict 'non-market' classification was dropped in December 1997, the EU reserves the right to judge Chinese exports on a sector by sector basis, and will continue to impose anti-dumping duties on goods from those sectors of the Chinese economy that remain subsidised by the state. ${ }^{20}$

While the EUs stance has irked Chinese policy makers, US policy towards China has been the main focus of Chinese attention and resistance. Sino-US economic relations have been punctuated by threats of trade wars, such as the threat to impose a $\$ 2$ billion tariff on Chinese textiles, electronics and consumer goods if Beijing did not take more forceful measures to deal with piracy of intellectual property rights. Furthermore, the annual vote in Washington over whether to facilitate Chinese access to the US market by renewing China's Most Favoured Nation trade preferences has generated considerable unease in Beijing. ${ }^{21}$

\section{Re-exports and the processing trade}

Foreign enterprises operating in China have taken an increasingly important role in promoting the growth of Chinese exports. The relationship between increased FDI flows and trade can be divided into two main sub-groups. The first is the increase in trade from those companies which primarily invest in China to access the huge potential domestic market. In establishing operations in China, the investors often bring with them equipment for their new factories. Indeed, the desire to encourage such technology imports was one of the main reasons that the Chinese authorities encouraged such investment in the first place, and investors have been granted tax exemptions on high-tech imports that the Chinese authorities feel will strengthen the technological base of the Chinese economy.

In addition to technology imports, this type of market-based investment has also generated increased exports from China. By restricting licenses to produce in China, the Chinese authorities have a firm bargaining position with potential investors. They have control over something that the 
investors want (ie access to the Chinese market) and can play off rival bidders against each other. Perhaps the best example of this process is the way in which the Chinese authorities restricted access to the potentially enormous Chinese automobile market, and then gained huge concessions from General Motors by continually keeping counter-offers from Ford on the table.

Thus many investors have been forced to sign agreements to export a proportion of whatever they produce in China. While the proportion of exports is typically less than half of total production, it can be much higher-Sony, for example, signed an agreement to export $70 \%$ of their production in China. As a result, China earns foreign currency, and the 'Made in China' hallmark becomes associated with high quality goods and respected brand names.

While market-based investment has increased China's foreign trade profile - both in terms of the volume and quality of traded goodsthe implications of the growth of 'export-based investment' has been even more significant, and has had a profound impact on both the growth and structure of Chinese trade. While the Chinese authorities may have hoped that FDI would help reinvigorate the domestic Chinese economy by using domestically produced components, investors have frequently complained about the poor quality and unreliability of Chinese supplies. Thus, the majority of these investors choose to import key components from existing plants overseas, with the Chinese sites typically only concentrating on labourintensive component assembly.

Thus export-based investment in China has resulted in a significant growth of both imports (in the form of components) and exports (of finished goods). From being an almost insignificant element of Chinese trade in the 1980s, it accounted for around half of all trade in 1997. ${ }^{22}$ This transition is reflected in the structure of Chinese trade. The majority of investors source their components from other production sites in Asia and sell their finished goods in the developed markets of the West. This has contributed to the situation where China now runs a massive trade surplus with the primary destination for processed exports, the USA, and trade deficits with those Asian states that are the source of component imports (notably South Korea and Taiwan).

The two exceptions in Asia are Japan and Hong Kong. There is evidence to suggest that Japanese companies are increasingly optimistic about the development of China as a major market for Chinese goods. ${ }^{23}$ 
However, the FDI-trade linkage remains a crucial determinant of Sino-Japanese trade. If Hong Kong subsidiaries of companies from other third states are taken out of the equation, then Japan is the biggest source of FDI in China. Note that imports from Japan increased by $70 \%$ in 1993 (66\% in real terms) - the year that FDI into China also boomed. In addition, Japanese companies often prefer to invest in China through subsidiaries in other East Asian states,24 while many independently owned Korean, Taiwanese and Hong Kong investors use high tech Japanese components in their Chinese operations. As such, simple bilateral trade figures understate the importance of Japanese goods in the development of China's processing trade.

As the most developed state in Asia, Japan is not only the major source of outward investment, but also the most lucrative market for finished goods in the region. Indeed, over a quarter of Japanese imports are goods produced by Japanese plants overseas, 25 and much of Japan's trade with China is effectively inter-company trade between different branches of Japanese multinational corporations, or `reverse imports’ of goods made by other Asian investors in China containing Japanese components.

The trade surplus with Hong Kong is explained by the subsequent re-export of goods to the West. For example, the proportion of Chinese exports to Hong Kong that are re-exported to the USA increased from $4.86 \%$ in 1979 to $41.6 \%$ in 1994 . In addition, just over half of all Hong Kong exports to China in 1994 were goods of US origin. ${ }^{26}$

The processing trade raises questions over the how we classify the 'nationality' of exports. If components are simply being assembled in China, are the resulting goods really Chinese? Jin Bei, from the Chinese Academy of Social Sciences, argues that we should distinguish between those exports that are produced by 'the national industry' and those that are 'non-domestically manufactured goods'. To count as real Chinese exports, the goods must be produced by Chinese enterprises or by companies where Chinese interests control share ownership. They should be produced with equipment and technology operated by Chinese technicians and with a 'certain figure' of Chinese components. Finally, for Jin Bei, brand-naming is the key to identifying the real 'country of origin'. It 'serves as an important indicator of the anationality ${ }^{\circ}$ of a product', and Chinese exports therefore should be labelled with Chinese trademarks. Those goods that meet most, but not all, of these requirements, should be called `para- 
domestically manufactured goods.’

Jin Bei argues that those products exported from China carrying foreign brand names produced with foreign materials and/or controlled by foreign managers and/or technicians simply should not be considered as made in China. He illustrates his argument with a case study of Pierre Cardin shirts produced at the Beijing Shirt Factory. These shirts retailed (at the time) at the equivalent of RMB300 in the West, yet the Beijing shirt factory only received RMB3 to RMB4 for each unit in processing fees:

Such goods do not primarily involve the actualization of China's productive forces, but the actualization of foreign productive forces in China, or the economic actualization achieved by turning Chinese resources into productive forces subject to the control of foreign capital owners. ${ }^{27}$

A more often cited example is the case of Barbie dolls. The case study was first reported in the USA itself in a Los Angeles Times report in 1996. ${ }^{28}$ The fact that the issue was raised in an American source has been seized on by the Chinese authorities, who cited the paper liberally in its White Paper 'On Sino-US Trade Balance' in $1997 .{ }^{29}$

Barbie dolls retailed in the USA at the time at around $\$ 10$ each, even though the unit import of each doll was a mere $\$ 2$. Although trade figures show a $\$ 2$ import from China, it is argued that this was an unfair representation of the real value of these exports to China. The raw materials for the plastics were imported into Taiwan from the Middle East, and the hair similarly exported to Taiwan from Japan. The goods were semifinished in Taiwan, and only then exported to China for the final stages of production. The real value to the Chinese economy was a mere 35 cents, with the remainder of the $\$ 2$ either already accounted for before the doll reaches China (65 cents) or in the cost of transportation from Hong Kong to the US (\$1).

The suggestion in this report was that the USA should not calculate China's trade surplus based on the value of the good that leaves China. Rather it should factor in the value of the good as it is imported into China, and consider the other elements to be part of its trade relationship with Taiwan, Japan and the Middle East. In other words, it is unfair, not to say wrong, to simply count the last country in a production chain as the country that you have a trade relationship with for that commodity. In particular, the diffused nature of production means that the final stage in the production chain is usually labour- intensive component assembly and/or finishing semifinished produce - in other words, areas with low value added. 
Indeed, in his assessment of China's role in the global economy, Lardy calculated that imported components typically account for $90 \%$ of the value of exports from foreign enterprises operating in China.30 As the processing trade now accounts for around half of all Chinese trade, the implication is that around half of the value of Chinese exports is in fact the value of goods imported from other states.

What the report on Barbie dolls didn't go on to mention is that Barbie is produced by the Mattel Company which has its headquarters in El Segundo in California. Mattel (which also produces Fisher Price, Matchbox, Cabbage-patch dolls, Disney, Pooh, Sesame Street, Nickelodeon and others) is only one of a number of US-based toy companies that have at least part of their production process located in China. It was the US toy industry that took the lead in trying to instigate a consumer boycott of cheap Chinese imports in the USA. Yet these US-based corporations are now making use of cheap labour in China to boost corporate profits.

It should be noted that it is not always easy to identify the extent of the involvement of US and other Western firms in the Chinese economy. As noted above, components are often routed through Hong Kong and/or Taiwan, or are produced by subcontractors in other parts of Asia. In addition, FDI is also often 'routed' through subcontractors in Asia. For example, the biggest shoe factory in the world is in Guangdong Province. This factory is a joint venture with $\mathrm{Yu}$ Yuan in Taiwan, and produces sports shoes carrying Reebok, Nike and Adidas labels. ${ }^{31}$ FDI and import statistics indicate the importance of relations with the rest of Asia and export figures show another Chinese export to Japan and the West-yet the brand names on the goods are associated with major Western corporations.

All this does not suggest that China has not benefited from the export of assembled goods. This has created jobs - although typically low wage and low skilled jobs - and generated income. But it does suggest that China has not gained as much as simply looking at bilateral figures for export growth initially suggests. Rather, we need to take a more holistic view of trade figures and consider the value added, rather than the nominal value, of exports. Indeed, perhaps we need to ignore nationally based statistics altogether, and consider inter and intra-company trade instead of national trade.

Thus, if we ask who benefits, we can identify Chinese partners in joint 
ventures. If we think that low paid, low skilled jobs in poor conditions are better than no job at all, then the workers in these enterprises can also be said to benefit. But we should not forget that major Western corporations are also benefiting greatly — and perhaps most - from this element at least of China's export growth.

\section{Export-led development and the impact of the Asian financial crises}

The Chinese were, of course, far from alone in failing to foresee the economic crises that hit many regional states in 1997. Had they been blessed with such foresight, they might not have chosen the same year to try and restructure their own domestic economy and place an even greater reliance on export-led growth. And notwithstanding the fact that China escaped the worst ravages of the regional crises in 1997, the crises have nevertheless had an important impact on the long-term viability of exportled growth.

On a very basic level, regional financial problems have simply undermined confidence, and turned the positive examples of other export-orientated regional states into negative examples of the dangers of liberalising too fully and too quickly. China shares many of the structural weaknesses that contributed to the crises in Malaysia, Thailand and Indonesia. It too has massive bank debts caused largely by the provision of non-performing loans to the state sector. It has invested millions of dollars in construction projects that people don't want. ${ }^{32}$ It also has an economy characterised by both oversupply and under-capacity. For example, in 1996 half of China's industry operated at below 60\% capacity, while the official Jingji Ribao (Economics Daily) indicated that stockpiles of goods that couldn't be sold exceeded RMB500 billion. ${ }^{33}$

The main reason why China didn't suffer the same fate as its regional neighbours was its relative lack of liberalisation and openness compared with other regional states. With a managed exchange rate underpinned by strict limitations and controls on currency convertibility, the renminbi was safe from attack by international speculators.

In addition, the 'hot money' that foreign investors had ploughed into capital markets in Southeast Asia could be, and was, rapidly removed. In China, the underdeveloped nature of Chinese stock and capital markets-perhaps we should say the immature and underdeveloped nature of Chinese capitalism — had also resulted in a different structure of foreign capital flows into China. The vast majority-indeed, almost all foreign capital inflows into China-were in longterm investment projects; foreign currency had built many more factories than it had purchased share certificates. 
In the aftermath of the crises, China's export-led growth strategy began to encounter new challenges. On one level, the problems in Japan, the region's most developed state, raised the prospect of a shrinking market for Chinese exports. On another level, the collapse of currencies in Southeast Asia meant that China lost its competitive advantage in export prices that it had gained from its own strategic and managed devaluation in 1994.

As China's relative lack of liberalisation had provided protection from the regional economic crises, the case for abandoning such protection and moving towards a more liberalised economy lost much of its force. It also provided those sceptics within the party the ammunition that they needed to call for a re-think and a postponement, if not abandonment, of liberalisation reforms.

The Chinese leadership's response to the regional crises illuminates their perceptions of the importance of export growth. The Chinese economy has continued to register the sort of growth rates that would delight many governments - but not the Chinese government. For example, when exports grew by $11.6 \%$ in the first four months of 1997, the government organised a televised national conference to announce the news. Rather than congratulate themselves on achieving such high growth, the party leadership instead used the conference to warn of an uncertain future. Exports were still growing, but the rate of growth had slowed. Similarly, while foreign investment had actually increased, the rate of increase had also slowed considerably.

When she addressed the conference and a national audience, State Councillor Wu Yi argued that the impact of the financial crises 'cannot be overestimated'. She argued that export growth should not be seen as a purely economic question, but also as a key political issue, as `proper export growth is critical in helping the nation reform State-owned enterprises, create jobs and promote social stability'. If export growth did not increase, then 'our course of opening up might also be affected'. ${ }^{34}$

At first sight, Wu Yi's comments appear to be disproportional to the problem. The explanation lies in a combination of the importance of job creation as a mechanism of ensuring social stability, and the relationship between export growth and the state of the domestic Chinese economy.

\section{Export growth, employment and social stability}

It is difficult to overestimate how seriously the Chinese government takes the threat to social instability from any increase in urban unemployment. Sporadic and uncoordinated cases of social disorder increased in 1998 and 
1999 largely in response to proposed closures and mergers of enterprises, unpaid welfare payments to laid-off workers, unpaid pensions from closed or loss-making enterprises, and to protest against official corruption. ${ }^{35}$

The government is officially committed to keeping urban unemployment below 4\%. In reality, Chinese researchers claim the urban unemployment rate is probably already nearer $8 \%$, as workers can be 'laid off' from their jobs for up to three years before they are officially classified as 'unemployed'. Furthermore, a national figure of less than $4 \%$ hides significant regional variations. While coastal regions that have attracted FDI have been able to create new jobs for both local workers and migrants from other parts of China, the unemployment problem is more acute in North East China and central provinces such as Hunan.

There are a number of explanations for the growth of unemployment explanations that have been well rehearsed in a number of publications by Hu Angang from the Chinese Academy of Social Sciences. ${ }^{36}$ These include demographic pressures that result in 10 million new entrants into the job market each year; technological advances; the steady flow of migrant workers from the countryside to the cities; and massive duplication of production that has turned the Chinese economy from one characterised by shortage in the 1970s to one characterised by oversupply in the 1990s.

While the structural causes of unemployment are deep seated and long term, two elements of the economic reforms associated with Zhu Rongji in the second half of the 1990s accelerated unemployment growth. First, Zhu reconfirmed his commitment to restructuring loss-making state-owned enterprises in 1997. In addition to resulting in around 10 million laid-off workers in two years, fears of potential job losses also dampened domestic demand. This leads us to the second factor. From 1994 Zhu Rongji instituted a deflationary strategy. This programme was highly successful in its own terms. The retail price index dropped from over $20 \%$ in 1994 to $2.6 \%$ in 1998 , while real GDP growth only fell from $12.6 \%$ to $7.8 \%$ (see Table 7).

This growth rate was by and large attained by an ever increasing reliance on exports as an engine for growth. Rather than being an important component in growth, exports all but became the sole generator of growth, and the safety net for domestic restructuring. They were a means of maintaining employment, creating new jobs, and essentially providing the opportunity to deal with the domestic economy while not sacrificing growth or dramatically increasing urban unemployment. Hence Wu Yi's concern that an $11.6 \%$ increase in exports might not be enough to allow the reforms to continue successfully. 
In the event, export growth remained strong in 1997, registering a $17.3 \%$ increase in real terms over 1996. However, the impact of the Asian financial crises was merely delayed, and export growth in 1998 was a mere $0.5 \%$. Indeed, if we denominate the figures in common US dollars, there was a decline in real terms of around 1\%. Domestic deflation in China resulted in a decline in imports in both 1997 and 1998, meaning that China's overall trade surplus continued to grow while export growth declined.

There are two main explanations for this decline in export growth. First, the reduction of demand from the crisis states. The collapse in the demand for exports in South East Asia hit specific industries - notably construction materials. More importantly, exports to Korea, China's second biggest export market in Asia, fell by almost a third. More important still was the decline in demand from Japan, with exports falling by $11.5 \%$ in 1998.

In the Korean and Japanese cases, declining domestic demand was exacerbated by increased price competition following the devaluation of regional currencies. The crises meant that China lost its competitive advantage in export prices that it had gained from its own strategic and managed devaluation in 1994. Exports from Malaysia and Indonesia were between 15\% and 40\% cheaper during 1998 than before the crash, while the Thai baht was 36\% lower against the Yuan than before the Chinese devaluation.

The decline in exports to the rest of Asia accounted for virtually all the overall drop in export growth. Indeed, exports to Europe and the USA grew by $15.3 \%$ and $16.1 \%$ respectively. Given China's ongoing trade disputes with the USA, and China's WTO entry ambitions, a combination of a decline in overall exports with an increase in both exports and trade surplus with the USA creates a potent set of challenges.

Not only is there a disparity between export growth to different markets, there is a disparity between export performance by different sectors of the Chinese economy. While exports by State Owned Enterprises declined by $5.8 \%$, exports from foreign invested enterprises increased by $8 \%$-indeed, exports by wholly foreign owned enterprises increased by $17.3 \%{ }^{37}$ It is particularly notable, and pertinent to the arguments in this article, that exports utilising imported components produced by foreign invested firms increased by $17.3 \%{ }^{38}$

It is clear that price competition from the Association of South East Asian 
Nations (ASEAN) states has damaged the export capability of 'domestic' exporters. But the situation in the processing trade is less clear. With so much of the value of these exports emanating from imported components, often from the rest of Asia, currency devaluations have decreased the unit costs of production. The key to maintaining China's comparative advantage in the processing trade is the retention of low labour costs combined with various incentives provided to attract FDI.

\section{Conclusions: the wrong type of exports?}

In many ways the Chinese experience of reintegration with the global economy provides a positive example for other developing states of how to manage international economic contacts. In particular, the maintenance of a relatively closed financial system provided a bulwark against speculative capital flows.

In foreign trade too, China's relative lack of openness has allowed the government to defend perceived national interests by protecting domestic producers and supporting exporters. But in the process, the notion of a 'national' interest has been brought ever more into doubt. The protection afforded to domestic producers, particularly state-owned enterprises, has protected employment and provided a safety net for urban workers during the transition from socialism. However, it has also contributed to the creation of a dualistic economy-one part reliant on the retention of at least an element of state control and protection, the other market and internationally orientated and, at the very least, less hostile to the further liberalisation of the Chinese economy.

Writing on a much earlier period of reform, Solinger argued that "The most obvious bases determining which point of view a particular group or institution is prone to support are the province in which it is located and the branch of industry with which it is connected." 39 This analysis by and large still holds true in response to calls for further liberalisation and opening to the global economy. Officials from those areas where state-owned enterprises still dominate the economy have been the most vocal in calling for restraint, and in criticising Premier Zhu Rongji for being over-zealous in attacking inflation and too eager to promote a liberalisation agenda. For these sceptics or conservers, the logic of devaluing the renminbi to restore the price competitiveness of exports and increase the price of competitive imports is convincing.

It was in many ways simply unfortunate that the Asian financial crises began to undermine Chinese export growth at a time when such export growth had become an increasingly important guarantor of growth. But the decision to use export growth as a means of maintaining employment while 
deflating the domestic economy made Chinese development strategies vulnerable to changes in the regional and global political economy. The lesson of the Chinese experience, and indeed also of the crisis states, is that an over-reliance on external markets relative to the domestic market entails a degree of risk that can affect even a relatively closed economy such as China. This is a lesson that the Chinese leadership themselves have learnt, moving from a deflationary strategy to a form of Chinese Keynsian expansion in an attempt to spend their way out of a potential crisis.

Finally, we need to question whether the growth of the processing trade provides a firm foundation for long term sustainable growth in China. The short-term requirements of job creation have been largely served — and the personal fortunes of those domestic interests that collaborate with external interests in establishing processing industries in China have been ensured. But the emphasis on China's low cost comparative advantage in labourintensive processing industries is doing little more than merely providing jobs - often jobs with low wages in poor conditions — for the short term.

The challenge is to move on from low value added assembly to new forms of production with greater value added that also develop China's skill and technology base. And to this end the Chinese authorities moved to restrict imports of cheap components in June 1999. This move was partly aimed at reducing imports from other Asian states that were damaging the position of vulnerable domestic producers. But according to Minister of Foreign Trade and Economic Cooperation, Shi Guangsheng, the Chinese authorities were also 'trying to encourage the processing sector to move toward a hitech and high value-added orientation' ${ }^{40}$

The problem is that neither the Chinese national government nor those more directly involved in the processing sector have autonomy in deciding how to participate in the international economy. In their analysis of Taiwanese investment in the Xiamen SEZ, Qi Lou and Howe show how the Xiamen authorities originally concentrated on attracting electronics manufacturers, and designed their local development strategy accordingly. However, Taiwanese investors had different priorities, and instead brought in more and more chemicals producers; 'faced with this divergence, the Xiamen authorities apparently abandoned their original goal and declared petrochemicals to be their new "investment emphasis". ${ }^{41}$ A similar process occurred in Shenzhen where the local leadership tried to restructure the local economy by imposing disincentives for processing industries and component assembly. While these industries did indeed decline, the hightech and financial investments that Shenzhen was hoping to attract were not forthcoming. As a result, the local authority reversed its policy, and 
reintroduced a number of incentives to lure back the processing and component assembly investments. ${ }^{42}$ And when the government in Beijing removed tax exemptions on imported goods used in foreign funded enterprises in 1996, FDI declined to such an extent that the government back-tracked and reintroduced tax exemptions on such imports from 1 January 1998.

\section{Having located China as a low cost assembly site in an international} division of labour, it is proving difficult to progress to a new stage. Given the perceived importance of employment as a guarantor of social stability for the Chinese elites, the chance that China will compete in a crowded international market ${ }^{43}$ by keeping production costs low is more likely than the transition to hi-tech production that the Chinese leadership favours.

\section{Notes}

Research at the Centre for the Study of Globalisation and Regionalisation is funded by the UK Economic and Social Research Centre, and the author gratefully acknowledges their support.

${ }^{1}$ Y J Zhang, China in International Society Since 1949: Alienation and

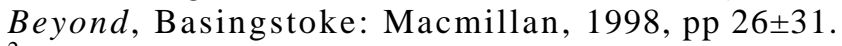

${ }^{2}$ Trade with the non-communist world nearly doubled between 1970 and 1974 . For details see J Howell, China Opens Its DoorsĐThe Politics Of Economic Transition, Boulder, CO: Harvester Wheatsheaf, 1993.

${ }^{3}$ Renato Ruggiero, 'China and the world trading system', Speech at Beijing University, 21 April 1997, with thanks to colleagues at Renmin University. ${ }^{4}$ By taking the World Bank's 1995 PPP calculations and adjusting them using Chinese growth figures.

${ }^{5}$ And while trade with the USA dominates discussions within China, similar discrepancies can be found in bilateral trade with virtually every nation: while China reported a US\$1473 million trade deficit with Germany in 1996, Germany reported that China had a US\$4690 million surplus. Zhongguo Tongji Nianjian (China Statistical Yearbook), Beijing: China Statistical Information and Consultancy Service Centre, 1997; and IMF, Direction Of Trade Statistics Yearbook, Washington, DC: International Monetary Fund, 1997.

${ }^{6}$ Imports are commonly calculated using CIF calculations.

${ }^{7}$ Even this figure is disputed, as the USA claims it is $80 \%$.

${ }^{8}$ Feng Guozhao \& Liu Zunyi, 'A new estimation on the trade imbalance between America and China', International Economic Review (Guoji Jingji

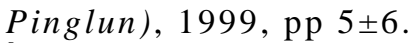

${ }^{9}$ Chen Qiuping, 'News Brief', Beijing Review, February 1993, p 15 (emphasis added).

${ }^{10}$ Adjusting for inflation using 1996 prices, a 53\% increase from $1993 \pm 95$.

${ }^{11}$ And others emerged outside the official structure.

${ }^{12}$ The situation was also complicated by the existence of Foreign Exchange Certificates (FECs). When foreigners in China changed currency, they were given FECs rather than normal Chinese renminbi. As these FECs could be used to purchase imported goods that were not available using renminbi, they acted as a quasi foreign currency, and a wide-scale black market in $\mathrm{RMB} \pm \mathbf{F E C}$ transfers emerged. 
${ }^{13} \mathrm{H}$ Dale, 'The economic integration of greater South China: the case of Hong-Kong Guangdong province trade' in J Chai, Y Y Kueh \& C Tisdell (eds), China and the Asia Paci ${ }^{\circledR}$ c Economy, Commack, NY: Nova Science, 1993, p 76.

${ }^{14} \mathrm{~K}$ Y Cheung, ‘Hong Kong's outward processing investment in China: implications for Hong Kong economy', in Chai, Kueh \& Tisdell, China and the Asia Paci ${ }^{\circledR}$ c Economy, p 105. 
Ts Speech by Mayor of Shenzhen at conference on 'China \pm EU Relations in the Global Political Economy’, Shenzhen, July 1998.

${ }^{16}$ Charlene Barshefsky, 'Statement of Ambassador Charlene Barshefsky Regarding Broad Market Access Gains Resulting from China WTO Negotiations', Office Of The United States Trade Representative, Washington, DC, 8 April 1999.

17 J Harding, 'Jitters in Beijing', Financial Times 10 November 1997, p 19. 18 China News Digest, 15 December 1996.

19 See N Niyonzima, 'The EU anti-dumping policy towards Asia', in S Dzever $8 \mathrm{~J}$ Jaussaud (eds), Perspectives on Economic Integration and Business Strategy in the Asia \pm Paci ${ }^{\circledR}$ C Region, Basingstoke: Macmillan, 1997, pp $62 \pm 76$.

${ }^{20}$ Indeed, the announcement of the relaxation in policy coincided with a request from the European Commission to impose a $49 \%$ duty on Chinese silicon metal exports.

21 These economic tensions have been exacerbated by the continued attempt, by what Chinese officials perceive to be anti-Chinese senators, to link access to the US market to non-economic issues such as improvements in human rights in China, the status of Tibet, nuclear technology transfer to Pakistan, the theft of US defence technology, and so on.

${ }^{22}$ And while this figure is significant in itself, the processing trade is even more important in those parts of China that have been the major recipients of FDI. In Guangdong, for example, the processing trade accounts for more than two-thirds of all provincial exports.

23 See R Taylor, 'Japanese investment strategy and management training in China’, Asian Affairs, 24, 1993, pp 315 \pm 326.

${ }^{24}$ See M Bernard \& J Ravenhill, 'Beyond product cycles and flying geese: regionalization, hierarchy, and the industrialization of East Asia', World Politics, 47, 1995, pp $171 \pm 209$.

${ }^{25} \mathrm{P}$ Katzenstein 'Regionalism in a comparative perspective', Cooperation and Conflict, 31 (2), 1996, pp 123ะ160.

${ }^{26}$ Y Y Kueh, 'China and the prospects for economic integration within APEC', in Chai, Kueh \& Tisdell, China and the Asia Paci ${ }^{\circledR}$ c Economy, pp $29 \pm 47$.

27 Jin Bei, 'The international competition facing domestically produced goods and the nation's industry', Social Sciences in China, 18 (1), 1997.

28 'Barbie and the world economy', Los Angeles Times, 22 September 1996. 29 State Council, On Sino-US Trade Balance, Beijing: Information Office of the State Council Of the People's Republic of China, March 1997. The example was also repeated on Chinese television on a number of occasions during Zhu Rongji's visit to the USA in March 1999.

${ }^{30} \mathrm{~N}$ Lardy, China and the World Economy, Washington, DC: Institute for International Economics, 1994. This may partly be explained by transfer pricing. Despite considerable liberalisation in China, many foreign companies still face problems in repatriating profits because of incomplete currency convertibility and the imposition of myriad ad hoc charges on the profits of foreign funded enterprises. Furthermore, those foreign interests operating joint ventures with Chinese companies or local authorities have to share a proportion of any profits with their Chinese partners. As such, it would be rational for foreign companies operating in China to locate as much of their profits as 
possible in operations outside China by overcharging factories in China for imported components supplied by factories in other countries.

${ }^{31}$ See A Chan 'Boot camp at the show factory: regimented workers in China's free labour market', Washington Post, 3 November 1996.

${ }^{32}$ For example, less than half of the offices in the new Pudong development zone in Shanghai had been occupied by the end of 1998 .

${ }^{33} \mathrm{~T}$ Walker, 'Stockpiles disguise China's slowdown: consumer industry growth leading to inventory build-up in factory warehouses', Financial Times, 21 March 1997.

${ }^{34}$ Wang Yong, 'Momentum vital for GDP exports require stimulus', China Daily, 21 May 1997.

${ }^{35}$ There were also a number of demonstrations fuelled by the problem of dealing with millions of refugees from the severe flooding of 1998.

${ }^{36}$ For example, Hu Angang, 'Unemployment and development: China's employment problem and employment strategy', World Economy and China, 7

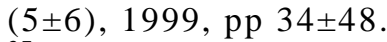

${ }^{37}$ Not least because of the increase in the number of wholly foreign owned enterprises.

${ }^{38}$ And processed exports of wholly foreign owned enterprises increased by $42.6 \%$.

${ }^{39}$ D Solinger, 'The Fifth National People's Congress and the process of policy making: reform, readjustment and the opposition', Issues and Studies, 18 (8), 1982, p 71.

40 China News Digest, 6 March 1999.

${ }^{41}$ Qi Lou \& C Howe, 'Direct investment and economic integration in the Asia Pacific: the case of Taiwanese investment in Xiamen', in D Shambaugh (ed), Greater China: The Next Superpower?, Oxford: Oxford University Press, 1995, pp $94 \pm 117$.

42 China News Service, 6 December 1995.

${ }^{43}$ And indeed, that local authorities within China will compete with each other. 